\title{
Utjecaj prehrane bogate cjelovitim žitaricama na metaboličke faktore rizika kod zdravih osoba i osoba s blagim stupnjem metaboličkoga sindroma
}

1 Sandra Hrg

1 Klinika za infektivne bolesti „Dr. Fran Mihaljević”, Mirogojska 8, 10000 Zagreb

\section{SAŽETAK}

Metabolički sindrom skupina je metaboličkih poremećaja čije je zajedničko obilježje poremećaj tolerancije glukoze, dislipidemija, hipertenzija i abdominalna pretilost. Cilj ovog teorijskog rada bio je prikupiti znanstvene i stručne članke te na temelju rezultata istraživanja procijeniti utjecaj aktivnih tvari cjelovitih žitarica i opravdanost redovitog unosa proizvoda od cjelovitog zrna žitarica na čimbenike rizika metaboličkoga sindroma i njegovu prevenciju.

Kao izvor podataka poslužile su studije na zdravim dobrovoljcima i osobama s blagim stupnjem metaboličkog sindroma (BMI $25-30 \mathrm{~kg} / \mathrm{m}^{2}$, koncentracija glukoze 5 - $6 \mathrm{mmol} / \mathrm{L}$, koncentracija ukupnog kolesterola $5-6 \mathrm{mmol} / \mathrm{L})$. Za procjenu utjecaja redovitog unosa cjelovitih žitarica na smanjenje rizika od razvoja dijabetesa tipa 2 (T2D) mjerene su vrijednosti glukoze u krvi, a utjecaj na tjelesnu masu (TM) ispitan je mjerenjem indeksa tjelesne mase (BMI) i opsega struka. Za procjenu kardiovaskularnih čimbenika rizika mjerene su vrijednosti kolesterola, triglicerida, kao i vrijednosti krvnoga tlaka te CRP-a (C-reaktivni protein). Osim mjerenja fizičkih parametara, u studijama se primjenjuju i verificirani upitnici za procjenu prehrambenih navika.
Konzumacija proizvoda s cjelovitim zrnom u usporedbi s rafiniranim žitaricama pomaže u regulaciji koncentracije glukoze u krvi te utječe na manje izražene hipoglikemije u fazi nakon obroka, sniženje vrijednosti indeksa tjelesne mase (BMI), kao i postotka visceralnoga masnog tkiva, krvnoga tlaka te CRP-a. Veći unos cjelovitih žitarica povezan je s redovitijom tjelesnom aktivnošću, većom potrošnjom povrća, voća, mliječnih proizvoda i nižom učestalošću pušenja, konzumiranja alkohola te smanjenim ukupnim dnevnim unosom energije.

Prema rezultatima istraživanja, unos proizvoda s cjelovitim zrnom zbog sinergije funkcionalnih sastojaka te tendencije poboljšanja korisnih životnih navika znatno je povezan s nižom učestalošću kroničnih bolesti odnosno metaboličkim sindromom.

Ključne riječi: žitarice, cjelovite žitarice, prehrana, metabolički sindrom

Datum primitka: 10.10.2017.

Datum prihvaćanja: 30.11.2017.

DOI: $10.24141 / 1 / 3 / 2 / 14$

Adresa za dopisivanje:

Sandra Hrg

Klinika za infektivne bolesti „Dr. Fran Mihaljević”

Mirogojska 8, 10000 Zagreb

Tel.: +385981643786

E-pošta:shrg@bfm.hr 


\section{UVOD}

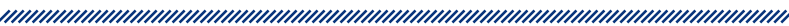

Prehrambene smjernice diljem svijeta preporučuju uključivanje cjelovitih žitarica, jer je sve više dokaza da cjelovite žitarice i proizvodi od cjelovitog zrna, osim što su izvor energije i hranjivih tvari, imaju i veliki utjecaj na zdravlje čovjeka. Komponente prisutne u cjelovitim žitaricama kojima se pripisuju korisna svojstva jesu vlakna, vitamini, minerali i fitokemikalije, uključujući fenole, karotenoide, lignane, $\beta$-glukan, inulin, rezistentni škrob, sterole i fitate. Saznanja govore u prilog bioaktivnim fitokemikalijama, koje povoljno utječu na zdravlje te smanjuju rizik od kroničnih bolesti, a istraživanja ukazuju na daleko veću zaštitnu ulogu cjelovitih žitarica u usporedbi s izoliranim hranjivih tvarima iz žitarica (vlakna, fitokemikalije...). Pozitivne tvrdnje o korisnom djelovanju cjelovitih žitarica postavljene su na temelju epidemiološkim studija koje uključuju milijune osoba kroz godine praćenja te ukazuju da je redovita konzumacija cjelovitih žitarica i njihovih proizvoda povezana sa smanjenim rizikom raznih vrsta kroničnih bolesti kao što su kardiovaskularne bolesti (KVB), dijabetes tipa 2 (T2D), dislipidemija i pretilost. Temeljeno na dokazima, za održavanje zdravlja, svakodnevno je potrebno konzumirati $14 \mathrm{~g} / 1000 \mathrm{kcal}$ (2/3 netopljivih i 1/3 topljivih vlakana) ili više cjelovitih žitarica, količina koju gotovo $80 \%$ stanovništva ne postigne u svakodnevnoj prehrani ${ }^{1,2}$.

S obzirom na velik broj rizičnih čimbenika za razvoj metaboličkog sindroma (Mets) na morbiditet i mortalitet, važno je preventivno djelovati na njegov razvoj. Uzrok ovog sindroma uglavnom je nepoznat, ali vjerojatno predstavlja složenu interakciju između genskih, metaboličkih i okolišnih čimbenika, što uključuje i prehranu. Metabolički sindrom obuhvaća nekoliko glavnih čimbenika rizika za KVB: dislipidemiju (povišena koncentracija triacilglicerida i niska razina HDL-a u krvi), intoleranciju glukoze i/ili inzulinsku rezistenciju te pretilost. Kriteriji su za dijagnosticiranje metaboličkoga sindroma prema definiciji ATP III (Adult Treatment Panel III) opseg struga $>102 \mathrm{~cm}$ za muškarce $\mathrm{i}>88 \mathrm{~cm}$ za žene, hipertrigliceridemija (> 1,7 mmol/L), snižena koncentracija HDL kolesterola ( $<1,036 \mathrm{mmol} / \mathrm{L}$ za muškarce i $<1,295 \mathrm{mmol} / \mathrm{L}$ za žene), arterijski tlak > 130/85 mmHg i koncentracija glukoze natašte $>6,1 \mathrm{mmol} / \mathrm{L}$. Procjena vrijednosti hsCRP-a svrha je pokazatelja upale, u ovom slučaju ateroskleroze, odnosno rizika od kardiovaskularnih bolesti. Mnoge studije ispituju potencijalne prehrambene navike kao intervenciju prvog izbora u prevenciji i liječenju posebice blagog stupnja metaboličkog sindroma koji karakteriziraju neznatno povišene vrijednosti pojedinih parametara (BMI $25-30 \mathrm{~kg} / \mathrm{m}^{2}$, koncentracija glukoze 5 - $6 \mathrm{mmol} / \mathrm{L}$, koncentracija ukupnog kolesterola $5-6 \mathrm{mmol} / \mathrm{L})$. Pozitivan utjecaj cjelovitih žitarica pripisuje se niskom glikemijskom indeksu i sinergiji nutritivnih komponenti ${ }^{3,4}$.

\section{FIZIOLOŠKI UČINCI CJELOVITIH ŽITARICA}

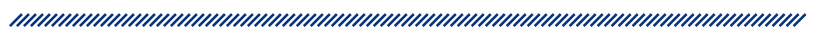

Podaci u literaturi govore da osobe koje konzumiraju tri ili više porcija cjelovitih žitarica dnevno imaju 20 do $30 \%$ manji rizik za patološke promjene na krvnim žilama u odnosu na osobe s nižim unosom. Promatran je učinak na redukciju LDL kolesterola, triglicerida i krvnog tlaka te povećanje HDL kolesterola. Predloženi potencijalni mehanizmi nisu u potpunosti razjašnjeni. Vjeruje se da dijelovi nekih žitarica, uključujući topiva vlakna, beta-glukan, alfa-tokotrienol te omjer arginina i lizina, igraju ulogu u snižavanju kolesterola u krvi. Cjelovite žitarice mogu smanjiti rizik od srčanih bolesti kroz sadržaj antioksidanasa, kao i ostalih bioaktivnih sastojaka koji igraju ulogu u vaskularnoj reaktivnosti i osjetljivosti inzulina ${ }^{5,6}$.

Rezultati studija ukazuju da redoviti unos cjelovitih žitarica može pridonijeti postizanju i održavanju TM-a. Osobe koje uključuju cjelovite žitarice kao dio prehrane imaju manju vjerojatnost povećanja TM-a tijekom vremena. Mehanizmi kojima cjelovite žitarice mogu podržati održavanje TM-a uključuju poboljšan osjećaj sitosti, smanjen unos energije, odgađanje želučanog pražnjenja i povećanu osjetljivost na inzulin, odnosno smanjenu potražnju gušterače za lučenjem inzulina ${ }^{7,8}$. Veća koncentracija dijetalnih vlakana i niža energetska gustoća obroka od cjelovitih žitarica, pretpostavlja se, rezultira smanjenim unosom energije i gubitkom TM-a. Nadalje, prehrambena vlakna mogu povećati fekalni gubitak masnoća, što također može pridonijeti negativnom energetskom balansu9.

Sve je više dokaza o smanjenju proupalnih markera kod osoba kojima je prehrana bogata cjelovitim zrnom žitarica. Na primjer, unos vlakana iz žitarica (> 8,8 g na dan), ali ne i vlakana iz drugih izvora, povezano je sa znatno nižom razinom citokina u plazmi kod zdravih odraslih 
osoba. Interventne studije pružaju dokaze da je razina citokina ili C-reaktivnog proteina smanjena nakon konzumacije pekarskih proizvoda koji sadrže ražene mekinje i kruh od cjelovitog zrna s mekinjama9.

Pretpostavlja se da komponente cjelovitih žitarica, uključujući Mg, vlakna, vitamin E, fitinsku kiselinu i fenoIne spojeve, pridonose smanjenju rizika od, kao i snižavanju razine glukoze i inzulina u krvi. Uočeno je da vlakna iz cjelovitih žitarica, za razliku od onih iz voća ili povrća, imaju veći zaštitni učinak u redukciji rizika za razvoj dijabetesa tipa 2. Veći unos cjelovitih žitarica povezan je s nižim razinama inzulina natašte, kao i s boljim markerima rizika u smislu niže koncentracije C-peptida i niže koncentracije homocisteina. Smjernice udruženja American Diabetes Association prepoznaju ulogu cjelovitih žitarica i vlakana u smanjenju rizika od dijabetesa tipa 2 i održavanju razine glukoze u krvi. Epidemiološke studije ukazuju da je smanjen rizik od 20 do $30 \%$ za razvoj dijabetesa tipa 2 povezan s višim unosom cjelovitih žitarica ili vlakana žitarica ${ }^{10}$.

\subsection{DIJETALNA VLAKNA I KRATKOLANČANE MASNE KISELINE}

Fiziološki utjecaj prehrambenih vlakana očituju se kroz sposobnost bubrenja odnosno povećanja volumena crijevnog sadržaja, što za posljedicu ima brži osjećaj sitosti i bolju peristaltiku. Preventivno djelovanje vlakana direktno je povezano s usporavanjem hidrolize polisaharida do glukoze te smanjenjem glikemijskog indeksa hrane zbog postupne razgradnje ugljikohidrata do glukoze (zbog vezanja s vlaknima, glukoza se postupno otpušta u krv i posljedično pridonosi manjem lučenju inzulina). Prehrambena vlakna tijekom prolaska kroz gastrointestinalni sustav (GIT) vežu žučne soli i kolesterol te ih izlučuju iz organizma ${ }^{11}$.

Jedan od mehanizama koji utječe na regulaciju metabolizma glukoze i lipida odnosi se na metabolizam neprobavljivih ugljikohidrata u debelom crijevu, s naglaskom na uvjetnu ulogu pojedinih metabolita kolona, SCFA. Fermentacija neprobavljivih ugljikohidrata i rezistentnog škroba (RS) u kolonu dovodi do formiranja metabolita, osobito SCFA-a (uglavnom octena, propionska i maslačna kiselina) i plinova (npr. vodika). lako se znatan dio SCFA-a gubi tijekom prolaska kroz jetru, jer većinu SCFA-a apsorbiranu iz lumena crijeva ekstenzivno metaboliziraju crijevna sluznica i jetra, frakcija može ući u sustavnu cirkulaciju i može se odrediti u perifernoj krvi. Kao predloženi mehanizam utjecaja konzumacije cjelovitih žitarica na koncentraciju glukoze u krvi postavlja se vjerojatnost da SCFA proizvedeni tijekom fermentacije neprobavljivih ugljikohidrata u debelom crijevu imaju blagotvoran učinak na metabolizam glukoze. Mogući su mehanizmi, pri čemu SCFA mogu poboljšati toleranciju glukoze, putem smanjenog motiliteta gastrointestinalnog trakta ili putem mehanizma koji uključuje povećano oslobađanje inkretina (GLP-1). Mjerene su jutarnje koncentracije acetata, propionata i butirata u plazmi nakon večernjeg obroka koji se sastojao od kruha na temelju zrna ječma. U studiji je sudjelovalo šest žena i 11 muškaraca. Kruh sa zrnom ječma za večernji obrok rezultirao je većim koncentracijama SCFA-a u plazmi u jutarnjim satima i nižim odgovorom glukoze (iAUC 0 - $120 \mathrm{~min}$ ) u usporedbi s bijelim kruhom u večernjem obroku. Rezultati podupiru stajalište da je izborom žitarica za večernji obrok moguće povećati crijevnu proizvodnju octene, propionske, a posebice maslačne kiseline (fermentacijom neprobavljivih UH-a u kolonu) do sljedećeg jutra te posljedično poboljšati toleranciju glukoze ${ }^{12}$.

Vlakna kao komponente žitarica cjelovitog zrna često su povezana s povoljnim učinkom na proupalne markere, uključujući C-reaktivni protein i interleukin-6. Konkretno, fermentacijom i proizvodnjom SCFA-a koji se vežu za G-protein vezani receptor, inhibirajući transkripcijski faktor $N f \kappa \beta$, povećava se prag upalnog odgovora na sluznicu debelog crijeva. Protuupalno djelovanje SCFA-a može se proširiti i izvan debelog crijeva, budući da ove bakterijske metabolite lako apsorbiraju kolonociti. Viskozitet topljivih vlakana ima važnu ulogu u njihovoj sposobnosti induciranja osjećaja sitosti. Obrok veće viskoznosti odgađa želučano pražnjenje i usporava probavu i apsorpciju glukoze, zbog smanjenja enzimske aktivnosti i mukozne apsorpcije, što dovodi do ranijeg osjećaja sitosti. SCFA reguliraju otpuštanje crijevnih hormona, koji igraju važnu ulogu u signalizaciji sitosti. Na regulaciju apetita djeluju preko nekoliko mehanizama. Prvo, imaju ulogu u usporavanju gastrointestinalnog motiliteta, tako kontroliraju probavu i apsorpciju nutrijenata, a dosadašnja saznanja ukazuju da mogu regulirati ukupno tranzitno vrijeme probave kroz debelo crijevo. SCFA isto tako reguliraju apetit moduliranjem otpuštanja različitih apetitom povezanih hormona u probavnom sustavu (PYY, kolecistokinin (CCK) i grelin). PYY se luči cijelom duljinom probavnog trakta, a najviša koncentracija nađena je u debelom crijevu i rektumu. Cirkulirajuće razine PYY-a najniže su u stanju gladovanja i povećavaju se nakon konzumiranja obroka. Sposobnost $\beta$-glukana da poveća otpuštanje PYY-a dokazano je u različitim skupinama stanovništva. Pro- 
ces fermentacije $\beta$-glukana i kasnije stvaranje SCFA-a pruža glavni mehanizam, $\beta$-glukanom inducirano otpuštanje PYY-a. Kod zdravih osoba kruh obogaćen sa 3 g ječmenog $\beta$-glukana inducira $16 \%$ viši ukupni PYY odgovor u usporedbi s kontrolnim kruhom. Čak i u pretilih muškaraca i žena pozitivan je odgovor razine PYY-a prilikom povećanja koncentracije zobenog $\beta$-glukana, $u$ rasponu od 2,16 g do 5,45 g po porciji, u prva četiri sata nakon obroka. Grelin igra važnu ulogu u reguliranju apetita te ima ulogu u homeostazi TM-a i energetskog metabolizma. Razina grelina u krvotoku raste nekoliko sati prije svakog obroka, a svoj vrhunac dosegne neposredno prije uzimanja obroka. Nakon uzimanja obroka nivo grelina pada. Kruh obogaćen sa $3 \mathrm{~g}$ ječmenog $\beta$-glukana rezultirao je $23 \%$ nižim odgovorom grelina od kontrolnog kruha ${ }^{12,13}$.

\subsection{MINERALNE TVARI}

Od minerala koji se uglavnom nalaze u proteinskim skladišnim vakuolama aleuronskih stanica ističu se magnezij i cink. Primjerice, pšenične mekinje sadrže $611 \mathrm{mg}$ magnezija na $100 \mathrm{~g}$, u usporedbi sa špinatom - $87 \mathrm{mg}$ na $100 \mathrm{~g}$, no tijekom obrade zrna većina je magnezija izgubljena (85\%). Kao kofaktor mnogih enzima kritičnih za metabolizam lipida, dokazano je da Mg utječe na smanjenje razine triglicerida i LDL-a u krvi te povećava razine HDL-a inhibicijom aktivnosti lecitin kolesterol acil-transferaze i 3-hidroksi-3-metilglutaril koenzim A reduktaze, a stimulirajući lipoprotein-lipazu. Nedovoljan unos magnezija povezan je s razvojem hipertenzije putem njegove aktivnosti kao vazodilatatora. Zapadnjačka prehrana uglavnom upućuje na nedovoljan unos magnezija pa se može zaključiti da redoviti unos cjelovitih žitarica ima potencijal spriječiti razvoj hipertenzije i drugih čimbenika KVB-a.

Veći unos cinka također predviđa manji rizik od dijabetesa 2. tipa. Zn se nalazi u pšeničnim klicama i mekinjama u količini od 7 do 12 mg na 100 g, što se može usporediti s drugim važnim izvorom, npr. govedina $(5-7 \mathrm{mg}$ na $100 \mathrm{~g})$. Međutim, približno $70 \%$ cinka ukloni se obradom u proizvodnji bijelog brašna. Na životinjskim modelima poremećaj proteina Znt8 (transportnog proteina cinka) u beta-stanicama ozbiljno remeti proizvodnju inzulina, dok je gubitak proteina Znt8 povezan s pretilošću, hiperglikemijom i hiperinzulinemijom. Mutacije u proteinu Znt8 povezane su s dijabetesom 2. tipa kod ljudi. Čini se mogućim da je prerada žitarica i nedostatka cinka u prehrani više od desetljeća uzrokovala veću incidenciju dijabetesa 2. tipa zbog kroničnog smanjenja lučenja inzulina, što je jedna od mnogih funkcija cinka, pogotovo kada je u kombinaciji s nižim unosom magnezija ili drugih komponenti cjelovitih žitarica. Može se zaključiti da uklanjanje minerala iz žitarica tijekom obrade, kao i neadekvatan unos cjelovitih žitarica utječe na razvoj dijabetesa 2. tipa, KVB-a i hipertenzije ${ }^{14}$.

\subsection{ANTIOKSIDANSI}

Konzumacija cjelovitih žitarica upućuje na pozitivan antioksidativni kapacitet kroz modulaciju glutation sustava. Istraživanja su pokazala da se aktivnost glutation peroksidaze u plazmi povećala za $15 \%$ kada su ispitanici konzumirali smeđu i crnu rižu tijekom šest tjedana. Mogući mehanizam učinka žitarica od cjelovitog zrna na ravnotežu glutationa objašnjen je iz in vitro dokaza koji ukazuju na mogućnost da flavonoidi mijenjaju ekspresiju gena odgovornih za sintezu i regulaciju glutationa. Za antioksidativni učinak cjelovitih žitarica odgovorna je prvenstveno ferulična kiselina. Oko $25 \%$ ferulične kiseline vjerojatno je čvrsto vezano i nije dostupno, ali ostaje $75 \%$ dostupne za gastrointestinalni trakt. $U$ prilog toj gastrointestinalnoj raspoloživosti stoji podatak da je konjugirana ferulična kiselina prisutna u krvi i urinu nakon obroka s mekinjama, ovisno o stupnju obrade namirnica. Istraživanja pokazuju da ferulična kiselina, kada se primjenjuje sa stanovišta oksidativnog stresa, smanjuje peroksidaciju lipida, smanjuje oksidativna oštećenja tkiva i sprječava pad glutationa i antioksidativnih enzima, a smatra se ključnim antioksidansom u ljudskoj fiziologiji. Većina fitokemikalija djeluju kao antioksidansi in vitro i imaju potencijal ublažiti oksidativni stres i upale koje su uključene u patogenezu metaboličkog sindroma. Različiti biomarkeri krvi i urina rutinski se primjenjuju kako bi se utvrdile metaboličke zdravstvene prednosti fitokemikalija. Na primjer, razina oksidiranih lipida u plazmi i urinu daju neizravnu mjeru kapaciteta fitokemikalija žitarica u zaštititi cirkulirajućih lipida od oštećenja uzrokovanih ROS-om. Osim toga, razine C-reaktivnog proteina i proupalnih citokina u plazmi indikativni su za stupanj sustavne upale, što je značajka mnogih bolesti metabolizma. lako je udio glavnih fitokemikalija, kao što su fenoli i flavonoidi, većina polifenola, čvrsto je vezana za stanične stijenke, čime je uvelike ograničena njihova biološka dostupnost u gornjem dijelu probavnog sustava. Zob sadrži najviše razine slobodnih ili nevezanih fenola (do $30 \%$ od ukupnih fenola), dok pšenica, ječam i raž sadrže vrlo nisku razinu (što je manje od 1,6 \%) pa određene vrste zobi imaju najveći potencijal za podizanje postprandijalnih koncentracija fenola u plazmi i antioksidativni kapacitet ${ }^{15}$. 


\section{RASPRAVA}

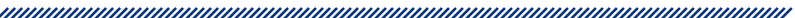

Rezultati studija potvrđuju da prehrana bogata cjelovitim žitaricama djeluje na regulaciju glukoze u krvi i smanjuje incidenciju razvoja dijabetesa tipa 2. Dosadašnja istraživanja ukazuju na važnost održavanja svih komponenti cijelog zrna žitarice u cilju regulacije glukoze i inzulina. Ispitivanje utjecaja proizvoda od cjelovitog zrna raži na odgovor inzulina i glikemijski profil (12 ispitanika / četiri mjeseca) rezultiralo je znatno nižim odgovorom inzulina nakon konzumacije raženog kruha s cjelovitim zrnom raži u usporedbi s kruhom od bijelog brašna i bijelog kruha u koji su dodane samo mekinje raži. Cjelovito zrno raži izaziva manje izražene kasne hipoglikemije. Određena topljiva vlakna utječu na viskoznost obroka, a time i glukozu u krvi, kao i osjetljivost inzulina, zbog njihova učinka na sporije pražnjenje želuca. Regulacija apetita proučavana je s obzirom na ukupnu koncentraciju grelina u plazmi u fazi nakon obroka s proizvodima od cjelovitog zrna raži jer dosadašnje studije ukazuju na povezanost ukupne koncentracije grelina s inzulinom. Istraživanjem je dokazano da obroci koji izazivaju visoke koncentracije inzulina u krvi (kruh od bijelog brašna) rezultiraju i većom koncentracijom grelina u kasnijoj fazi nakon obroka $(r=0,34, p<0,01)$. Proizvodi s cjelovitim zrnom raži, koji rezultiraju znatno nižim koncentracijama glukoze i inzulina u krvi, mogu smanjiti osjećaj gladi u kasnijoj fazi nakon obroka (niže koncentracije grelina) i eventualno smanjiti unos energije u usporedbi s obrokom kao što je doručak s kruhom od bijeloga pšeničnog brašna ${ }^{16}$.

Veliko grupno istraživanje žena u postmenopauzi (72 215 ispitanica kroz sedam godina praćenja) ukazalo je na pozitivnu ulogu konzumacije cjelovitih žitarica s rezultatom manjeg broja incidenata T2D. Ispitanice koje su konzumirale više od dvije porcije cjelovitih žitarica dnevno imale su $43 \%$ manji rizik od razvoja dijabetesa u odnosu na ispitanice koje nisu konzumirale cjelovite žitarice. $U$ ovom istraživanju zaključena je relativno niska prosječna potrošnja cjelovitih žitarica (1,1 obrok na dan) pa autori zaključuju da čak i malo povećanje unosa takvih proizvoda može smanjiti rizik od razvoja dijabetesa. Žene s višim unosom cjelovitih žitarica bile su i fizički aktivnije te su konzumirale više voća, povrća i mliječnih proizvoda. Rezultati ove studije dodatno ukazuju na to da je zaštitni učinak cjelovitih žitarica dijelom povezan s mikronutrijentima, uključujući magnezij, vitamin D, folnu kiselinu i kalij. Vlakna u cjelovitim žita- ricama svoj zaštitni učinak ispoljavaju putem izravnih crijevnih učinaka. Posebno topiva vlakna usporavaju apsorpciju hrane kroz probavni sustav te su pokazala bolje postprandijalne odgovore glukoze ${ }^{17}$.

Da je konzumacija bijele riže povezana s većim rizikom od razvoja dijabetesa tipa 2, za razliku od smeđe riže (slika 1), pokazala je obrada podataka upitnika tri prospektivne kohortne studije kod žena i muškaraca u dobi 26 do 87 godina. Unos bijele riže u količini od 300 grama na dan ili više od dva obroka na dan u ovoj je analizi povezan sa $78 \%$ povećanim rizikom od razvoja dijabetesa tipa 2 u odnosu na unos količina manjih od $200 \mathrm{~g}$ na dan. Ispitanici koji su unos bijele riže zamijenili smeđom rižom imali su niži rizik od razvoja dijabetesa tipa 2. No još znatnije smanjenje rizika od razvoja dijabetesa tipa 2 imali su ispitanici koji su konzumaciju bijele riže zamijenili kombinacijom cjelovitih žitarica. Takvi rezultati objašnjeni su činjenicom da uključivanje više

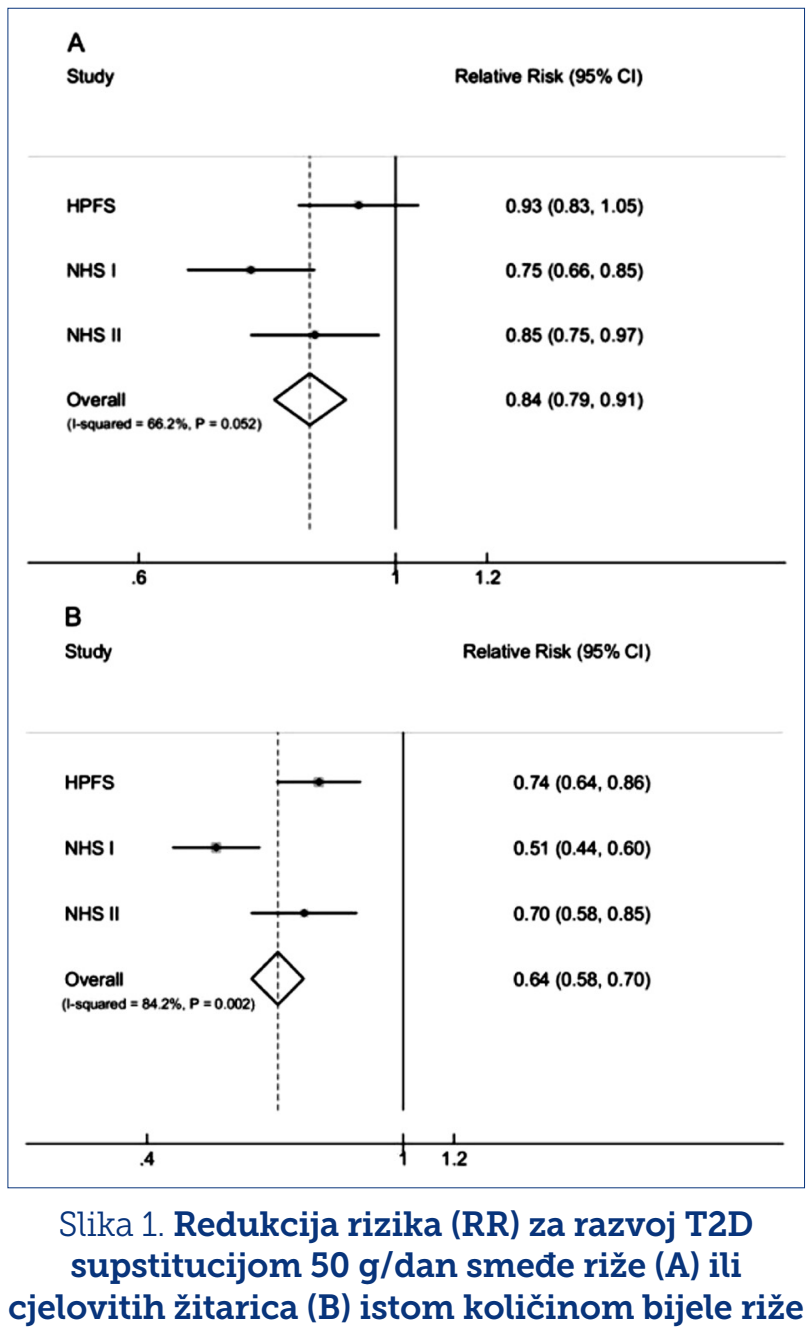


žitarica s različitim nutritivnim sastavom rezultiraju različitim učincima na odgovor glukoze s obzirom na njihov glikemijski indeks (GI). Tako npr. cijelo zrno pšenice i ječma rezultiraju nižim odgovorom glukoze nego smeđa riža ( $G I 41 \pm 3$ za cijelo zrno pšenice, $25 \pm 1$ za ječam, $55 \pm 5$ za smeđu rižu). Obrada (rafiniranje) riže uključuje gubitak vlakna, vitamina, magnezija, lignana, fitoestrogena i fitinske kiseline - faktora koji su odgovorni za smanjen rizik razvoja dijabetesa tipa 2. Neobrađena zrna riže sadrže gotovo isključivo netopiva vlakna koja su povezana s poboljšanom osjetljivošću na inzulin. Osim toga, veći unos magnezija putem neobrađenih žitarica povezan je $s$ poboljšanim metabolizmom glukoze $u$ dotadašnjim kliničkim studijama ${ }^{18}$.

Od devet crossover istraživanja koja su se bavila proučavanjem povezanosti unosa cjelovitih žitarica i TM-a sedam studija pokazalo je korelaciju između višeg unosa cjelovitih žitarica sa znatno nižim vrijednostima indeksa tjelesne mase (BMI) i opsega struka. Usporedbom grupa ispitanika s različitim unosom žitarica (cjelovite i rafinirane žitarice) zaključena je redukcija TM-a, ali sa znatno većim smanjenjem (-3\%) visceralnoga masnog tkiva u skupini koja je konzumirala cjelovite žitarice. Dokumentirano je također znatno smanjenje postotka masnog tkiva u abdominalnoj regiji $(P=0,03)$ kod ispitanika koji su imali ciljani broj dnevnih obroka s cjelovitim žitaricama (79 žena u postmenopauzi s prekomjernom tjelesnom masom). Znači, prehrana bogata cjelovitim žitaricama ne utječe znatno na smanjenje TM-a, ali rezultira smanjenjem udjela centralne tjelesne masti koja je prediktor razvoja KVB-a. Autori tumače da bi mehanizmi koji stoje iza takvog učinka mogli biti povezani s nižim postprandijalnim odgovorima inzulina i glukoze, što ima utjecaja na lipolizu i oksidaciju lipida umjesto skladištenja masti ${ }^{19,20}$.

Ispitivanjem u trajanju od 12 tjedana, za koje je regrutirano 50 osoba s metaboličkim sindromom, utvrđeno je pospješuje li prehrana koja uključuje žitarice s cjelovitim zrnom uz smanjen unos energije (umanjen unos za $500 \mathrm{kcal}$ na dan) redukciju TM-a (slika 2). Uočeno je znatno $(P=0,01)$ smanjenje vrijednosti CRP-a (slika 3), važnog pokazatelja kardiovaskularnih događaja, u skupini koja je konzumirala integralne žitarice, što autori tumače kao posljedicu nižih koncentracija glukoze tijekom dana (posljedica povećanog unosa vlakana), a može biti i posljedica smanjenoga oksidativnog stresa kao rezultata antioksidansa iz cjelovitih žitarica ili pak posljedica smanjenog oslobađanja upalnih citokina masnog tkiva. Ispitanicima koji su unosili određen broj obroka s cjelovitim žitaricama znatno se $(P<0,01)$ povećao unos magnezija i dijetalnih vlakana (za gotovo $14 \mathrm{~g} / 1000$ kcal), što se smatra najboljom poveznicom prehrane i rizika od KVB-a. Sudionici su također smanjili unos zasićenih masti, kolesterola, natrija i dodanih šećera. Ukupni LDL i HDL kolesterol znatno su smanjeni $(P<0,05)$ u odnosu na početne vrijednosti u obje skupine ${ }^{20}$.

Tijekom dvogodišnjeg praćenja osoba s najvišim unosom mješavine cjelovitih žitarica i mekinja uočeno je smanjenje BMI-ja za 7,2 \%. Utjecaj takve prehrane na BMI posljedica je više mehanizama, a to su niža energetska gustoća i glikemijski indeks obroka koji potječe od cjelovitih žitarica, fermentacija neprobavljivih ugljikohidrata (brža signalizacija osjećaja sitosti), kao i modulacija crijevne mikroflore ${ }^{21}$.

Zanimljivi su rezultati studije kojom je uspoređen unos cjelovitih žitarica ispitanika na terapiji statinima. Ispitanici čija je prehrana bila bogatija cjelovitim žitaricama ( $\geq 16$ g cjelovitih žitarica na dan) imali su niže vrijedno-

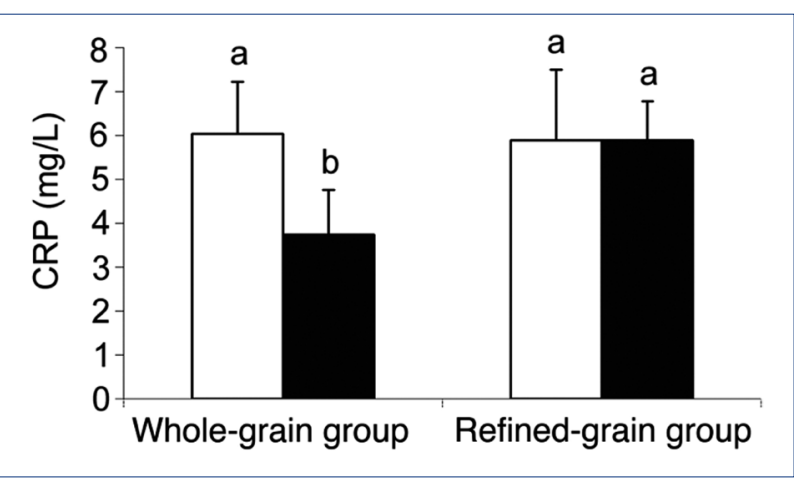

Slika 3. CRP vrijednosti nakon konzumacije cjelovitih i rafiniranih žitarica

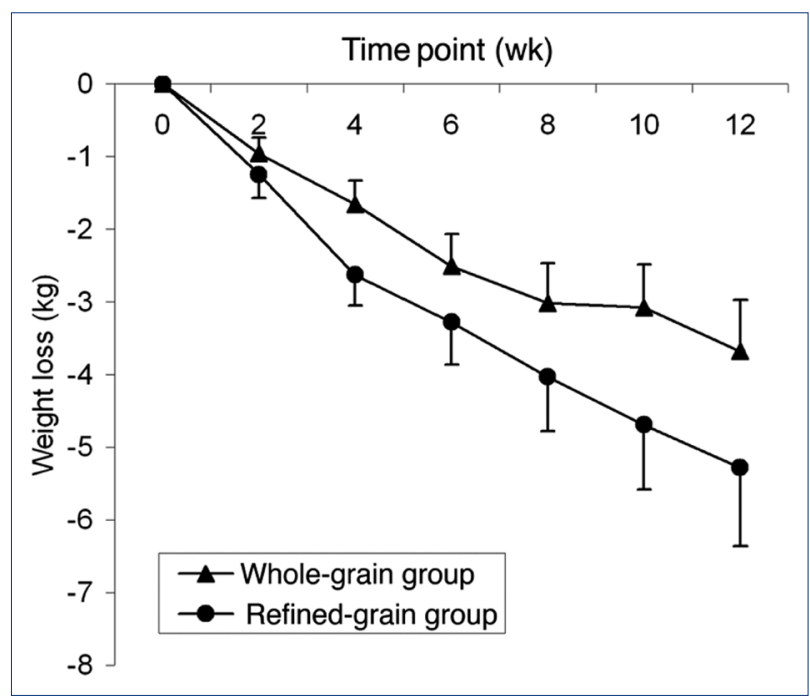

Slika 2. Utjecaj konzumacije žitarica na TM 
sti ukupnog kolesterola u usporedbi s ispitanicima koji su uz terapiju statinima konzumirali $<16 \mathrm{~g}$ integralnih žitarica na dan ${ }^{22}$.

Veći unos cjelovitih žitarica u obrnutoj je korelaciji s ukupnim i LDL kolesterolom (slika 4) pa poboljšanje lipidnog profila može biti potencijalni posrednički put kojim cjelovite žitarice smanjuju smrtnost od KVB-a. Uzimajući u obzir činjenicu da namirnice bogate viskoznim vlaknima utječu na koncentraciju LDL kolesterola, istražen je utjecaj cjelovitog zrna zobi u sastavu žitarica za doručak na regulaciju kolesterola. Studija je uključila muškarce i žene s hiperkolesterolemijom i prekomjernom tjelesnom masom. Razina LDL kolesterola smanjena je za $8,7 \%$, uz regulaciju lipoproteina, a rezultati pokazuju i smanjenje visceralnoga masnog tkiva ${ }^{23}$.

Kardioprotektivni učinak cjelovitih žitarica ocijenjen je na temelju mjerenja krvnog tlaka, lipida u serumu i upalnih markera. Slijepo, randomizirano kontrolirano ispitivanje uključivalo je 233 sudionika (muškarci i žene od 40 do 60 god.). Rezultati su pokazali da dnevna konzumacija tri obroka cjelovitih žitarica znatno smanjuje sistolički krvni tlak i vrijednosti pulsa (slika 5 A, B i C), što može smanjiti učestalost bolesti koronarnih arterija za $\geq 15 \%$ i moždanog udara za više od $25 \%$. Dnevni unos vlakna 10 do $15 \mathrm{~g}$ kroz osam tjedana bio je povezan s padom SBP-a (sistolički krvni tlak) između 1 i $3 \mathrm{mmHg}^{24}$.

Na osnovi pretpostavke da proizvodi od cjelovitih žitarica posjeduju korisna svojstva za regulaciju apetita, analiziran je utjecaj instantnih zobenih pahuljica (IO), standardnih zobenih pahuljica (SO) i komercijalnih žitarica za doručak (RTEC) na osjećaj sitosti s obzirom na karakteristike $\beta$-glukana i viskoznost obroka. Obroci zobene kaše (IO) pokazali su najveću učinkovitost u regulaciji apetita. Veći udio $\beta$-glukana u zobi, veća hidracija

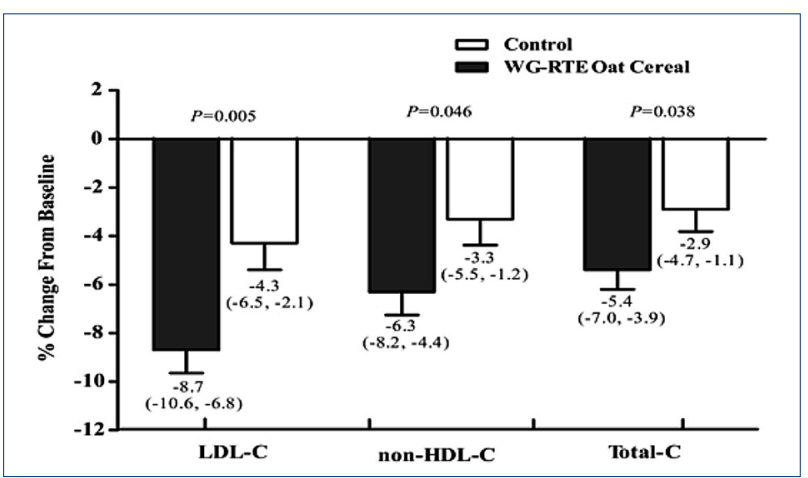

Slika 4. Vrijednosti lipoproteina na početku i tijekom trajanja studije
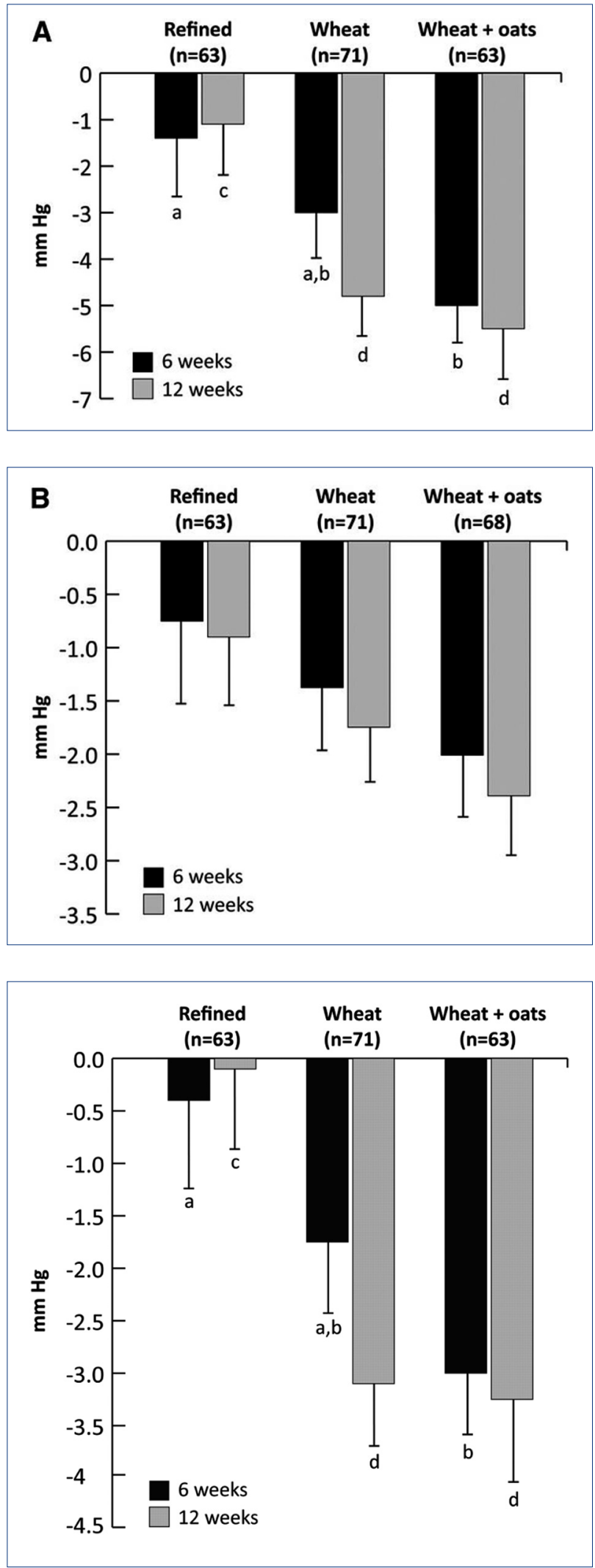

Slika 5. Razlika u SBP-u (A) i DBP-u (B) te pulsu $(C)$ nakon 6 i 12 tjedana intervencije 
vlakana instantnih zobenih pahuljica koja uvjetuje veću viskoznost obroka, a ujedno fermentacija neprobavljivih ugljikohidrata rezultiraju bržom signalizacijom osjećaja sitosti, a time i regulacijom TM-a ${ }^{25}$.

Cilj placebom kontroliranoga randomiziranog ispitivanja bio je procijeniti ulogu polifenola žitarica. Osamdeset zdravih pretilih ispitanika kroz osam tjedana konzumiralo je proizvode od cjelovitog zrna, što je rezultiralo četiri puta većim povećanjem serumske dihidroferulične kiseline (DHFA) u usporedbi s kontrolnom skupinom. Povećana koncentracija fekalne ferulične kiseline (FA) povezana je s većom brojnosti vrsta Bifidobacteriales i Bacteroidetes, ali smanjenom brojnosti vrsta Clostridium ${ }^{26,27}$.

\section{ZAKLJUČCI}

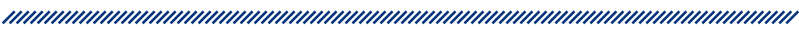

Pregled niza studija ukazuje na to da je prehrana bogata cjelovitim žitaricama povezana s nižom prevalencijom metaboličkog sindroma. Randomizirane, kontrolirane studije o prehrani ljudi, kao i druga eksperimentalna istraživanja pružaju dokaz o uzročnoj vezi između konzumacije cjelovitih žitarica i metaboličke homeostaze te odgađanje, kao i sprječavanje razvoja kroničnih bolesti i njihovih komplikacija u različitim skupinama.

1. Viša razina unosa proizvoda od cijelog zrna povezana je s nižim razinama glukoze natašte.

2. Dnevni unos $\geq 2$ porcije cjelovitih žitarica smanjuje rizik razvoja dijabetesa tipa 2 za $43 \%$.

3. Konzumacija cjelovitih žitarica podupire crijevnu proizvodnju kratkolančanih masnih kiselina (SCFA), octene, propionske, a posebice maslačne kiseline, koje utječu na bolju toleranciju glukoze, pa se smatra da je to jedan od mehanizama kojima cjelovite žitarice utječu na smanjen rizik od razvoja dijabetesa tipa 2 i KVB-a.

4. Prehrana bogata cjelovitim žitaricama ima tendenciju smanjivanja udjela masnog tkiva u području abdomena, što je u skladu sa smanjenjem opsega struka i bokova kod ljudi te posljedično prevencija KVB-a.

5. Redovita konzumacija proizvoda od cjelovitog zrna žitarica utječe na smanjenje TM-a i BMI-ja.

6. Veći udio $\beta$-glukana u žitaricama, veća hidracija vlakana koja uvjetuje veću viskoznost obroka od cjelovitih žitarica te fermentacija neprobavljivih ugljikohidrata rezultiraju bržom signalizacijom osjećaja sitosti, a time i regulacijom TM-a.

7. Veći unos mješavine cjelovitih žitarica u obrnutoj je korelaciji s profilom lipida u serumu.

8. Dnevna konzumacija tri obroka cjelovitih žitarica $(\sim 48 \mathrm{~g})$ povezana je s nižim sistoličkim i dijastoličkim krvnim tlakom te vrijednostima pulsa.

9. Konzumacija cjelovitih žitarica smanjuje vrijednosti CRP-a, važnog pokazatelja upale.

10. Prevalencija metaboličkog sindroma znatno je niža u ispitanika koji su konzumirali tri obroka cjelovitih žitarica dnevno u usporedbi s onima koji unose $<1$ porcije tijekom dana.

Za realizaciju potencijalnih korisnih učinaka cjelovitih žitarica potrebna je edukacija kako struke tako i javnosti općenito o prednostima njihove konzumacije, a za utvrđivanje dugoročnih zdravstvenih prednosti potrebna su daljnja istraživanja s dužim trajanjem kako bi se što točnije identificirale bioaktivne komponente odgovorne za ove korisne metaboličke značajke.

\section{LITERATURA}

"

1. Borneo R, León AE. Whole grain cereals: functional components and health benefits. Food Funct. 2012; 3(2): 110-119.

2. Slavin J. Whole grains and human health. Nutr Res Rev. 2004; 17(1): 99-110.

3. Djoussé L, Padilla H, Nelson TL, Gaziano JM, Mukamal KJ. Diet and metabolic syndrome. Endocr Metab Immune Disord Drug Targets. 2010; 10(2): 124-137.

4. Reiner Ž, Laganović M. Metabolic Syndrome - Relationship between Insulin Resistance, Arterial Hypertension and Microalbuminuri. Medicus. 2004; 13(2): 57-65.

5. Blaton V, Korita I, Bulo A. How is metabolic syndrome related to dyslipidemia? Biochemia Medica. 2008; 18(1): 14-24.

6. Anderson JW. Whole grains protect against atherosclerotic cardiovascular disease. Proc Nutr Soc. 2003; 62(1): 135-142.

7. Fung TT, Rimm EB, Spiegelman D, Rifai N, Tofler GH, Willett WC, et al. Association between dietary patterns and plasma biomarkers of obesity and cardiovascular disease risk. Am J Clin Nutr. 2001; 73(1): 61-67.

8. Metelko Ž, Crkvenčić N. Sindrom metaboličke inzulinske rezistencije i metabolizam ugljikohidrata. Medicus. 2004; 13(2): 41-49.

9. Kristensen M, Toubro S, Jensen MG, Ross AB, Riboldi G, Petronio $\mathrm{M}$, et al. Whole grain compared with refined 
wheat decreases the percentage of body fat following a 12-week, energy-restricted dietary intervention in postmenopausal women. J Nutr. 2012; 142(4): 710-716.

10. Montonen J, Knekt P, Järvinen R, Aromaa A, Reunanen A. Whole-grain and fiber intake and the incidence of type 2 diabetes. Am J Clin Nutr. 2003; 77(3): 622-629.

11. Brody T. Nutritional Biochemistry. San Diego: Academic Press; 2006. 113-115.

12. Nilsson AC, Östman EM, Knudsen KE, Holst JJ, Björck IM. A cereal-based evening meal rich in indigestible carbohydrates increases plasma butyrate the next morning. J Nutr. 2010; 140(11): 1932-1936.

13. El Khoury D, Cuda C, Luhovyy BL, Anderson GH. Beta Glucan: Health Benefits in Obesity and Metabolic Syndrome. J Nutr Metab. 2012. 28 str.

14. Hu FB, Manson JE, Stampfer MJ, Colditz G, Liu S, Solomon CG, et al. Diet, lifestyle, and the risk of type 2 diabetes mellitus in woman. N Engl J Med. 2001; 345(11): 790-797.

15. Belobrajdic D, Bird AR. The potential role of phytochemicals in wholegrain cereals for the prevention of type-2 diabetes. Nutr J. 2013; 12: 62.

16. Rosén LAH, Blanco Silva LO, Andersson UK, Holm C, Östman EM, Björck IME. Endosperm and whole grain rye breads are characterized by low post-prandial insulin response and a beneficial blood glucose profile. Nutr J. 2009; 8: 42.

17. Parker ED, Liu S, Van Horn L, Tinker LF, Shikany JM, Eaton $\mathrm{CB}$, et al. The association of whole grain consumption with incident type 2 diabetes: the Women's Health Initiative Observational Study. Ann Epidemiol. 2013; 23(6): 321-327.

18. Sun Q, Spiegelman D, van Dam RM, Holmes MD, Malik VS, Willett WC, et al. White rice, brown rice, and risk of type 2 diabetes in US men and women. Arch Intern Med. 2010; 170(11): 961-969.

19. Giacco R, Della Pepa G, Luongo D, Riccardi G. Whole grain intake in relation to body weight: from epidemiological evidence to clinical trials. Nutr Metab Cardiovasc Dis. 2011; 21(12): 901-908.
20. Katcher HI, Legro RS, Kunselman AR, Gillies PJ, Demers LM, Bagshaw DM, et al. The effects of a whole grain-enriched hypocaloric diet on cardiovascular disease risk factors in men and women with metabolic syndrome. Am J Clin Nutr. 2008; 87(1): 79-90.

21. Cho SS, Qi L, Fahey GC Jr, Klurfeld DM. Consumption of cereal fiber, mixtures of whole grains and bran, and whole grains and risk reduction in type 2 diabetes, obesity, and cardiovascular disease. Am J Clin Nutr. 2013; 98(2): 594-619.

22. Wang $\mathrm{H}$, Lichtenstein $\mathrm{AH}$, Lamon-Fava $\mathrm{S}$, Jacques PF. Association between statin use and serum cholesterol concentrations is modified by whole-grain consumption: NHANES 2003- 2006. Am J Clin Nutr. 2014; 100(4): 1149-1157.

23. Maki KC, Beiseigel JM, Jonnalagadda SS, Gugger CK, Reeves MS, Farmer MV, et al. Whole-grain ready-to-eat oat cereal, as part of a dietary program for weight loss, reduces lowdensity lipoprotein cholesterol in adults with overweight and obesity more than a dietary program including lowfiber control foods. J Am Diet Assoc. 2010; 110(2): 205-214.

24. Tighe P, Duthie G, Vaughan N, Brittenden J, Simpson WG, Duthie $S$, et al. Effect of increased consumption of wholegrain foods on blood pressure and other cardiovascular risk markers in healthy middle-aged persons: a randomized controlled trial. Am J Clin Nutr. 2010; 92(4): 733-740.

25. Rebello CJ, Chu YF, Johnson WD, Martin CK, Hongmei $\mathrm{H}$, Bordenave $\mathrm{N}$, et al. The role of meal viscosity and oat $\beta$-glucan characteristics in human appetite control: a randomized crossover trial. Nutr J. 2014; 13: 49.

26. Vitaglione P, Mennella I, Ferracane R, Rivellese AA, Giacco $\mathrm{R}$, Ercolini $\mathrm{D}$, et al. Whole-grain wheat consumption reduces inflammation in a randomized controlled trial on overweight and obese subjects with unhealthy dietary and lifestyle behaviors: role of polyphenols bound to cereal dietary fiber. Am J Clin Nutr. 2015; 101(2): 251-261.

27. De Angelis M, Montemurno E, Vannini L, Cosola C, Cavallo N, Gozzi G, et al. The role of whole-grain barley on human fecal microbiota and metabolome. Appl Environ Microbiol. 2015; 81(22): 7945-7956. 